University of Wollongong

Research Online

Faculty of Engineering and Information

Faculty of Engineering and Information

Sciences - Papers: Part B

Sciences

2020

Overload damage mechanisms of GFRP-RC beams subjected to highintensity low-velocity impact loads

\author{
Zein Saleh \\ University of Wollongong, zs492@uowmail.edu.au \\ M Neaz Sheikh \\ University of Wollongong, msheikh@uow.edu.au \\ Alex M. Remennikov \\ University of Wollongong, alexrem@uow.edu.au \\ Abheek Basu \\ University of Wollongong, abheek@uow.edu.au
}

Follow this and additional works at: https://ro.uow.edu.au/eispapers1

Part of the Engineering Commons, and the Science and Technology Studies Commons

Research Online is the open access institutional repository for the University of Wollongong. For further information contact the UOW Library: research-pubs@uow.edu.au 


\title{
Overload damage mechanisms of GFRP-RC beams subjected to high-intensity low-velocity impact loads
}

\author{
Abstract \\ This paper investigates the overload capabilities and damage mechanisms of Glass Fiber Reinforced \\ Polymer (GFRP) bar reinforced concrete beams subject to high-intensity low-velocity impact loads. The \\ overload condition of the beam is defined as the capability of the beam to sustain input impact energy \\ exceeding its quasi-static energy absorption capacity. Nine GFRP bar reinforced concrete (GFRP-RC) \\ beams were tested under three levels of increasing input impact energy. The shear capacities of the \\ beams were varied by using three spacings of the shear reinforcement. The midspan deflection histories, \\ impact loads, reaction forces, and accelerations of the beams were measured. The crack patterns and \\ failure modes were recorded and analyzed using a high-speed video camera. It was found that the beam \\ shear capacity significantly influenced the type of cracks and the development of cracks under increasing \\ levels of impact energy. Flexural and flexure-shear cracks were observed in the beams with higher shear \\ capacities whereas shear cracks were observed in the beams with lower shear capacities. It was also \\ found that higher beam shear capacities led to reduced residual midspan deflections and higher residual \\ load carrying capacities of the beams. Design recommendations are provided for GFRP-RC beams \\ subjected to high-intensity low-velocity impact events.

\section{Disciplines} \\ Engineering | Science and Technology Studies

\section{Publication Details} \\ Saleh, Z., Sheikh, M., Remennikov, A. \& Basu, A. (2020). Overload damage mechanisms of GFRP-RC \\ beams subjected to high-intensity low-velocity impact loads. Composite Structures, 233 \\ 111578-1-111578-12.
}


1 Overload Damage Mechanisms of GFRP-RC Beams Subjected to High-intensity

\section{Low-velocity Impact Loads}

aPhD Student, School of Civil, Mining and Environmental Engineering, University of Wollongong,

5 Australia

${ }^{\mathrm{b} A s s o c i a t e}$ Professor, School of Civil, Mining and Environmental Engineering, University of

7 Wollongong, Australia

8 'Professor, School of Civil, Mining and Environmental Engineering, University of Wollongong,

9 Australia

10 Lecturer, School of Mechanical, Materials, and Mechatronic Engineering, University of

11 Wollongong, Australia

*Corresponding author. Tel: + 6124221 3009; Fax: + 612 4221 3238; Email: msheikh@uow.edu.au

\section{ABSTRACT}

This paper investigates the overload capabilities and damage mechanisms of Glass Fiber Reinforced Polymer (GFRP) bar reinforced concrete beams subject to high-intensity low-velocity impact loads. The overload condition of the beam is defined as the capability of the beam to sustain input impact energy exceeding its quasi-static energy absorption capacity. Nine GFRP bar reinforced concrete (GFRP-RC) beams were tested under three levels of increasing input impact energy. The shear capacities of the beams were varied by using three spacings of the shear reinforcement. The midspan deflection histories, impact loads, reaction forces, and accelerations of the beams were measured. The crack patterns and failure modes were recorded and analyzed using a high-speed video camera. It was found that the beam shear capacity significantly influenced the type of cracks and the development of cracks under increasing levels of impact energy. Flexural and flexure-shear cracks were observed in the beams with higher shear capacities whereas shear cracks were observed in the beams with 
lower shear capacities. It was also found that higher beam shear capacities led to reduced residual midspan deflections and higher residual load carrying capacities of the beams. Design recommendations are provided for GFRP-RC beams subjected to high-intensity low-velocity impact events.

keywords: Reinforced concrete beam; GFRP; design guidelines; shear; failure mode; impact

\section{Introduction}

Reinforced Concrete (RC) structures may be subjected to sudden dynamic loads including impact loads during the lifetime of the structures. Impact loads are characterized by a high intensity load over a short period of time, which include fall of heavy objects, rock fall, impact of debris carried by tornadoes, accidental impact of vehicles, and terrorist attacks. With the increase in the terrorist attacks and vehicle accidents globally, impact loads need to be considered in the design phase of the critical infrastructure for protecting the critical infrastructure from catastrophic failure [1].

Several studies investigated the impact response of traditional steel bar reinforced concrete (SteelRC) beams [2-12]. Fujikake et al. [2] developed a correlation between the maximum midspan deflection of Steel-RC beams and the degree of the flexural damage under impact loads. Fujikake et al. [13] proposed a model to predict the maximum midspan deflection for Steel-RC beams failing in flexure under impact loads and evaluated the damage of the beams using the correlation developed in Fujikake et al. [2]. Yi et al. [14] assessed the likelihood of Steel-RC beams to fail in shear under impact loads. The influence of the impact velocity on the failure mode and crack profile of Steel-RC beams was extensively investigated in the literature. Saatci and Vecchio [4] reported that regardless of the impact velocity, severe diagonal cracks appeared at the impact area of the beam forming shear plugs. Kishi et al. [15] reported that Steel-RC beams failed in flexure under low-velocity impact loads. However, the failure mode of steel-RC beams changed from flexure to shear when the impact velocity increased. Zhao et al. [9] also reported that an increase in the impact velocity led to shear failure of Steel-RC beam. Moreover, several experimental and numerical studies were carried out to investigate 
the influence of the loading rate and the residual resistance of Steel-RC beams $[5,6,16-18]$. The available studies in the literature focused mainly on the flexural and shear responses of Steel-RC beams under low-velocity impact loads where low-velocity impact loads are considered to have an impact velocity up to $10 \mathrm{~m} / \mathrm{s}$.

Glass Fiber Reinforced Polymer (GFRP) bars have emerged as suitable replacements to the steel reinforcing bars in RC structures [19, 20]. GFRP bars have many advantages over steel bars including higher tensile strength and strength-to-weight ratio. In addition, GFRP bars do not corrode and they are electromagnetic neutral. The GFRP bar reinforced concrete (GFRP-RC) structures are mostly desirable in corrosive and marine environments. However, the modulus of elasticity of the GFRP bars is lower than the modulus of elasticity of steel bars, which leads to larger deformations of the GFRPRC structures compared to Steel-RC structures. Moreover, the bond strength of the GFRP bars in the GFRP-RC structures is weaker than the bond strength of steel bars in Steel-RC structures. The bond characteristics of GFRP-RC beams have been thoroughly investigated in the literature [21-29]. Moreover, since GFRP bars do not have a clear yield point, a different design approach needs to be considered for the design of GFRP-RC beams [30-34]. The flexural behavior of GFRP-RC beams under quasi-static and impact loads was investigated in the literature. Most studies in the literature focused mainly on the flexural behavior of GFRP-RC beams under quasi-static loads [26, 27, 35-40]. A few recent studies investigated the behavior of GFRP-RC beams under impact loads [41-43]. Goldston et al. [41] tested GFRP-RC beams under impact loads with an input impact energy equal to the quasi-static energy absorption capacity. However, no studies in the literature investigated the behavior of GFRP-RC beams under an input impact energy higher than the quasi-static energy absorption capacity of that beam.

This paper investigates experimentally the overload damage mechanisms of GFRP-RC beams under high-intensity low-velocity impact loads. In total, nine GFRP-RC beams were tested under impact loads using the high-capacity impact testing facility at the University of Wollongong. Significant influences of the shear reinforcement and impact velocity on the dynamic shear behavior 
of the GFRP-RC beams were observed. The results of this study will help in understanding the shear behavior of GFRP-RC beams under high-intensity low-velocity impact loads including failure modes, midspan deflections, and dynamic forces.

\section{Experimental program}

\subsection{Details of the tested beams}

The experimental program comprised nine GFRP-RC beams tested under low-velocity impact loads. In addition, one GFRP-RC control beam was tested under quasi-static loads. As shown in Fig. 1, all the beams were $200 \mathrm{~mm}$ in width, $300 \mathrm{~mm}$ in height, and $2400 \mathrm{~mm}$ in length. The clear concrete cover on the top, bottom, and sides was $25 \mathrm{~mm}$. The GFRP-RC beams were longitudinally reinforced with $16 \mathrm{~mm}$ diameter GFRP bars. Two bars were placed at the tension side and two bars were placed at the compression side. Fig. 1 shows the reinforcement details and the dimensions of the tested beams. All beams were designed as over-reinforced beams according to ACI [30] and Australia [32]. The GFRP shear reinforcement was calculated according to ACI [30] and Australia [32]. The GFRP stirrups had a diameter of $12 \mathrm{~mm}$. In this study, according to Australia [32], the maximum spacing of transverse reinforcement shall not exceed $0.6 d_{v}$ or $400 \mathrm{~mm}$, where $d_{v}$ is the effective shear depth. According to ACI [30], the maximum spacing of transverse reinforcement shall not exceed the smaller of $d_{e f f} / 2$ or $600 \mathrm{~mm}$, where $d_{e f f}$ is the effective depth of the beam. Therefore, the maximum spacing of transverse reinforcement was chosen as $150 \mathrm{~mm}$. In order to study the influence of the shear capacities on the damage mechanisms, the center-to-center spacing of the stirrups varied for the three different groups of tested beams. The stirrup spacing of $150 \mathrm{~mm}, 100 \mathrm{~mm}$, and $75 \mathrm{~mm}$ were used in the tested beams which corresponded to the spacing of $D / 2, D / 3$ and $D / 4$, where $D$ is the beam depth. The details of the GFRP-RC beams were been reported in Table 1. Moreover, six accelerometers were mounted to the side of the GFRP-RC beams to capture the accelerations across the beams during impact. 


\subsection{Material properties}

To determine the compressive strengths of concrete, nine concrete cylinders were tested on 28 days of concrete casting, on the first day of testing (day 78), and the last day of testing (day 138). The MATEST Servo-Plus Evolution machine was used to test the concrete cylinders. For the nine tested beams and the control beam, the target compressive strength of concrete was $50 \mathrm{MPa}$. The average compressive strength of concrete at 28 days was $52.5 \mathrm{MPa}$. The average compressive strength of concrete between the first day of testing and last day of testing was 59.3 MPa. To determine the ultimate strength and modulus of elasticity of the GFRP bars used, tensile tests were carried out on five GFRP bar specimens of diameter $16 \mathrm{~mm}$. An INSTRON tensile machine was used for the tensile testing of the GFRP bars. Strain gauges were attached to the GFRP bars to measure the strains during the tests. The average ultimate strength of the GFRP bars was $957 \mathrm{MPa}$ and the average modulus of elasticity of the GFRP bars was $47.1 \mathrm{GPa}$.

\subsection{Experimental program}

One GFRP-RC beam was tested under a quasi-static three-point bending load as a control beam. A pin support and a roller support were at a distance of $200 \mathrm{~mm}$ from the beam ends. Monotonically increasing loads were applied at the midspan of the control beam at a rate of $1 \mathrm{~mm} / \mathrm{min}$. The applied load was recorded using a load cell. The midspan deflection of the control beam was recorded using a laser displacement transducer ACUITY AR550-250. Fifty millimeter square grids were marked across the beam to track the development and position of cracks on the beams. The energy absorption capacity of the control beam was calculated as the area under the load-midspan deflection curve [44, 45]. The three impact velocities were then chosen based on the energy absorption capacity of the control beam to deliver the impact energy as a multiple of the quasi-static energy absorption capacity of the control beam. A detailed explanation of the choice of impact velocities is presented in the following sections.

Nine GFRP-RC beams were tested under low-velocity impact loads using the high-capacity impact testing facility at the University of Wollongong. The mass of the drop hammer was $600 \mathrm{~kg}$. The 
impact load and dynamic beam reactions were measured using high-capacity load cells attached to

127 the impact hammer and supports, respectively. The flat round impactor plate with a diameter of 300

$128 \mathrm{~mm}$ was attached to the drop hammer load cell. Fig. 2 presents the beam setup in the impact testing

129 facility. Rebound frames were used at the beam ends to prevent the uplift of the beams during the

130 impact. A $5 \mathrm{~mm}$ rubber pad was placed on top of the beam at the impact zone to protect it from

131 crushing by the impactor. A MEMRECAM HX-7 high-speed video camera was used to record the

132 impact and the propagation of cracks at 5000 frames/sec. Six accelerometers were mounted to each

133 beam along the length to measure the accelerations and derive the dynamic shear forces.

134 To investigate the effects of shear capacity on the impact behavior of the GFRP-RC beams, the

135 nine beams were divided into three groups according to the shear reinforcement spacing. Each group

136 included one beam with the maximum spacing of stirrups of $150 \mathrm{~mm}$ or $D / 2$, according to ACI design

137 provisions for shear design [30]. Other common spacing of $D / 4(75 \mathrm{~mm})$ and $\mathrm{D} / 3(100 \mathrm{~mm})$ were

138 also used for designing the beams. The beams in each group were subjected to the same impact

139 velocity that was selected based on the quasi-static energy absorption capacity of the control beam.

140 The beams were referred to as a series of numbers indicating the spacing of shear reinforcement and

141 the corresponding impact velocity. For example, Beam 150-6.5 represents a GFRP-RC beam with a

142 spacing of stirrups of $150 \mathrm{~mm}$ and tested under an impact load with a velocity of $6.5 \mathrm{~m} / \mathrm{s}$. All

143 experimental data were recorded at a sampling rate of $100 \mathrm{kHz}$. The test set-up ensured that each

144 group of beams had three different shear reinforcement spacing and was subjected to the same impact 145 velocity.

146 3. Experimental results and discussion

\section{$147 \quad 3.1$ Quasi-static loading}

148 The quasi-static load testing was carried out by loading the control beam until failure at a rate of

$1491 \mathrm{~mm} / \mathrm{min}$. The load-midspan deflection behavior was nearly bilinear until failure (Fig. 3).

150 Afterwards, there were fluctuations in the peak loads as the beam continued deflecting. The first part 
151 of the bilinear behavior represents the stiffness of the uncracked response of the beam. At a load of

$15222 \mathrm{kN}$, concrete under tension cracked and the stiffness of the beam dropped. The second part of the

153 behavior represents the post-cracking behavior. The load increased until the first peak of $170 \mathrm{kN}$. The

154 deflection corresponding to the first peak load was $45.4 \mathrm{~mm}$. At the first peak load, the cracks in the

155 beam were flexural cracks, starting from the tension side and propagating vertically upwards. Also,

156 the cracks in the concrete cover in the compression zone were visible. After the first peak load, the

157 load dropped to $148 \mathrm{kN}$. The load then increased until it reached the second peak at $178 \mathrm{kN}$. The

158 deflection corresponding to the second peak load was $59.3 \mathrm{~mm}$. At the second peak load, concrete in

159 compression crushed and the load dropped to $164 \mathrm{kN}$. The load increased again until it reached the

160 third peak at an ultimate load of $180 \mathrm{kN}$. The deflection corresponding to the ultimate load was 65.8

$161 \mathrm{~mm}$. At the ultimate load, the GFRP bars in tension ruptured and the beam collapsed. The control

162 beam failed in flexure and the cracks observed were predominantly flexural cracks. The quasi-static

163 energy absorption capacity " $E$ ” of the control beam was calculated as the area under the load-midspan

164 deflection curve in Fig. 3. A similar approach was adopted in the studies relating the quasi-static

165 energy absorption capacity of the beam to the input impact energy [41, 46]. The energy absorption

166 capacity was equal to 8684 Joules. Using this energy absorption capacity, the three impact velocities

167 applied on the three groups of beams were chosen as $5.5 \mathrm{~m} / \mathrm{s}, 6.5 \mathrm{~m} / \mathrm{s}$, and $7.5 \mathrm{~m} / \mathrm{s}$.

168 Nine beams were tested under impact loads. After the impact loads test, the beams were tested

169 under quasi-static three-point bending to measure their residual capacities. The residual load-carrying

170 capacities (residual capacities hereafter) of the beams were considered to be the ultimate load-

171 carrying capacities of the damaged beams recorded under the quasi-static three-point bending. These

172 residual capacities were then compared to the ultimate load-carrying capacity of the control beam

$173(180 \mathrm{kN})$. Based on the observed behavior of the tested beams, when the residual capacity of the beam

174 was over $90 \%$ (meaning the residual load-carrying capacity was over $162 \mathrm{kN}$ ), the damage was

175 considered to be minor. If the residual capacity of the beam was between $80 \%$ and $90 \%$ (residual 
load-carrying capacity between $144 \mathrm{kN}$ and $162 \mathrm{kN}$ ), the damage was considered to be medium. If

177 the residual capacity of the beam was lower than $80 \%$, the damage was considered to be severe.

178

179

180

181

182

183

184

\subsection{Impact loading}

The impact energy was calculated from the evaluation of the kinetic energy (impact energy $=$

$\left.\frac{1}{2} m v^{2}\right)$, where $m=600 \mathrm{~kg}$ is the mass of the impactor and $v$ is the impact velocity. Impact velocities for Groups 1-3 were estimated from the energy balance between the impactor kinetic energy and multiples $(1.0,1.5$, and 2.0) of the quasi-static energy absorption capacity of the control beam. Therefore, the three impact velocities chosen were $5.5 \mathrm{~m} / \mathrm{s}, 6.5 \mathrm{~m} / \mathrm{s}$, and $7.5 \mathrm{~m} / \mathrm{s}$. Impact tests were carried out to determine the failure modes, crack propagation, midspan deflections, residual midspan deflections, and dynamic forces of the GFRP-RC beams tested under impact loads.

\subsubsection{Effect of inertia on beams under impact loads}

The impact load is generated when the drop hammer impacts the beam [4]. This impact load is resisted by the stiffness of the beam while the beam accelerates downwards. The inertia load is produced by the beam acceleration. The magnitude of this inertia load is discussed in the sections below. The inertia load acts in the opposite direction to the acceleration of the beam. Therefore, since the beam accelerates downward, the inertia load acts upwards along the span of the beam. The dynamic bending moments and shear forces are different in shape and magnitude from the quasistatic bending moments and shear forces. At the initial stage of the impact loading, the inertia load had a significant influence on the response of the beam. This was explained in details in the "dynamic equilibrium of applied forces" section.

\subsubsection{Analysis of damage mechanisms}

\section{Group 1 beams}

Analysis of damage mechanisms of the tested beams was performed by conducting a frame-byframe analysis of the high-speed video recordings for each beam. Fig. 4 presents the damage progression of the beams belonging to Group 1 at the three time instances. The first row presents the 
effect of beam inertia resistance (at $t=1 \mathrm{~ms}$ ). The second row presents the beam damage at the 202 maximum midspan deflection (at $t=22-23 \mathrm{~ms}$ ). The third row presents the post-impact damage of 203 the beams. The first column presents the damage of progression of Beam 150-5.5. The other two 204 columns present the beams with higher shear capacities (Beam 100-5.5 and Beam 75-5.5).

205 The first impact loads test was carried out for Beam 150-5.5 (spacing of stirrups of $D / 2$, impact 206 velocity of $5.5 \mathrm{~m} / \mathrm{s}$ ). During the first millisecond of impact loading, two inclined shear cracks (cracks 2071 and 2) originating from the impact zone appeared along with flexural cracks (crack 3) (Fig. 4). The 208 shear cracks propagated at 45 degrees. As the beam continued deflecting, the shear cracks (cracks 1, 2092 , and 8) widened and additional flexural cracks appeared (cracks 4-7). At $t=23 \mathrm{~ms}$, Beam 150-5.5 210 reached its maximum midspan deflection. The shear cracks dominated the damage response of Beam 211 150-5.5 and were wider than the flexural cracks. In addition to that, local damage of concrete was 212 observed at the impact zone. As the beam rebounded to its initial position, the impactor bounced a 213 few times on the beam before resting on it. The bouncing of the impactor caused additional local 214 damage at the impact zone. However, the reinforcement was not exposed. The maximum midspan 215 deflection of Beam 150-5.5 was $61.4 \mathrm{~mm}$ and the residual deflection was $10 \mathrm{~mm}$ (Table 2). The 216 residual deflection of Beam 150-5.5 was $16 \%$ of the maximum midspan deflection. Three-point quasi217 static loads test was carried out after the impact on Beam 150-5.5 to determine the residual capacity 218 of the beam. It was found that the residual capacity of Beam 150-5.5 was $153 \mathrm{kN}$, which was $85 \%$ of 219 the load-carrying capacity of the control beam. This meant that the damage of Beam 150-5.5 could 220 be considered as medium.

221 Next, impact loading test was carried out for Beam 100-5.5 (spacing of stirrups of $D / 3$ ). During 222 the first millisecond of impact loading, a flexural crack (crack 1) at the midspan of the beam was 223 observed as the beam started deflecting (Fig. 4). As Beam 100-5.5 continued deflecting, additional 224 flexural cracks (cracks 2-4, 8), flexure-shear cracks (cracks 5 and 6), and shear cracks (crack 7) were 225 observed. This behavior showed a transition in the damage mechanism from shear-plug under the 
impact point to flexure-shear upon increasing the shear capacity of the beam. Also, it was observed 227 that the shear cracks appeared after the flexural cracks in Beam 100-5.5. At $t=23$ ms, Beam 100-5.5 228 reached its maximum midspan deflection and the cracks reached their maximum widths. Local failure 229 of the concrete at the impact zone was clearly observed. The diagonal shear cracks (i.e., crack 7) were 230 the dominant cracks. The shear cracks were wider than the flexural cracks. As the beam returned to 231 its initial position, most of the flexural cracks closed. However, the shear cracks were still visible. 232 The post-impact damage of Beam 100-5.5 is presented in Fig. 4. It can be observed that the damage 233 at the impact zone did not expose the GFRP reinforcement bars. The measured maximum midspan 234 deflection and residual deflection were $60.9 \mathrm{~mm}$, and $6 \mathrm{~mm}$, respectively. The residual deflection of 235 Beam 100-5.5 was 9\% of the maximum midspan deflection. The residual capacity of Beam 100-5.5 was $166 \mathrm{kN}$, which was $92 \%$ of the load-carrying capacity of the control beam. This indicated that the damage of Beam 100-5.5 could be considered as minor.

The final impact loading test for Group 1 beams was carried out for Beam 75-5.5 with a spacing of stirrups $75 \mathrm{~mm}$, or $D / 4$. As the beam started deflecting, it was observed that during the first millisecond of impact loading the first flexural cracks appeared (cracks 1 and 2) (Fig. 4). As Beam 75-5.5 continued deflecting, additional flexural (cracks 3, 7, 8, and 9), shear (cracks 5 and 6), and flexure-shear (cracks 4 and 10) cracks started appearing. The inclined shear cracks originated from the impact zone and propagated at an angle of 45 degrees. It was observed that the shear cracks 244 appeared after the flexural cracks. The cracks appearing during the first millisecond of impact were 245 due to the inertia effect of the beam. Beam 75-5.5 reached the maximum midspan deflection at $t=22$ $246 \mathrm{~ms}$ where the cracks reached the maximum widths. It was observed that at $t=22 \mathrm{~ms}$, when the beam was at its maximum midspan deflection, the shear cracks were not dominant in the damage mechanism. The widths of the flexural cracks and the shear cracks were similar. The higher shear capacity of Beam 75-5.5, in comparison to Beam 100-5.5, prevented the development of severe shear 250 cracks. The failure mode of Beam 75-5.5 was observed to be dominated by the flexural response. 251 Local damage and post-impact cracks at the impact zone were observed. However, the GFRP 
reinforcing bars were not exposed. The maximum midspan and residual deflections were $59.2 \mathrm{~mm}$ and $4 \mathrm{~mm}$, respectively. The residual deflection was $7 \%$ of the maximum midspan deflection. The residual capacity of Beam 75-5.5 was $175 \mathrm{kN}$, which was $97 \%$ of the load-carrying capacity of the control beam. This could be considered as minor damage of Beam 75-5.5.

It was observed for Group 1 beams that the width of cracks was influenced by their shear capacities. An increase in the shear capacity led to a decrease in the width of cracks. Moreover, diagonal shear cracks of shear-plug type were observed for beams with a larger spacing of stirrups and a lower shear capacity (Beam 150-5.5), whereas flexural cracks were observed for beams with a higher shear capacity (Beam 75-5.5). This also shows that during the beam inertia resistance stage, the shear capacity significantly influences the damage mechanism in a beam. Flexural damage mechanisms started developing during the initial inertia stage of impact loading in Beam 75-5.5, whereas shear-plug damage mechanisms started developing within the duration of inertia load in Beam 150-5.5. In addition to that, the beam shear capacity significantly affected the residual loadcarrying capacities of the beams. Beams with a higher shear capacity demonstrated a higher postimpact load-carrying capacity.

\section{Group 2 beams}

The impact velocity was increased for Group 2 beams to $6.5 \mathrm{~m} / \mathrm{s}$. This impact velocity transferred 13026 Joules of impact energy into Group 2 beams which is 50\% higher than the impact energy used

for Group 1 beams. The beam 150-6.5 (spacing of stirrups of $D / 2$ ) was tested first in this group. During the inertia loading stage, shear crack (crack 3) and flexural cracks (cracks 1 and 2) appeared in the beam (Fig. 5). The shear crack was more dominant than the flexural cracks. As Beam 150-6.5 continued deflecting, some of the flexural cracks became flexure-shear cracks (crack 2). Moreover, additional shear cracks were formed (crack 5). Some of the initial flexural cracks (crack 1) did not increase significantly in width due to the presence of a dominant adjacent flexure-shear crack (crack 2). At $t=26 \mathrm{~ms}$, Beam 150-6.5 reached its maximum midspan deflection and the cracks reached their 
maximum widths. The dominant cracks were the flexure-shear cracks (crack 2) and shear cracks

(crack 3). Local damage was observed and the GFRP stirrups and longitudinal bars were exposed, (Fig. 5). The residual deflection was $20 \%$ of the maximum midspan deflection. The residual loadcarrying capacity of Beam 150-6.5 was $132 \mathrm{kN}$, which was $73 \%$ of the load-carrying capacity of the control beam. This indicated that the damage of Beam 150-6.5 could be classified as severe.

For the second impact loading test in Group 2, Beam 100-6.5 (spacing of stirrups of $D / 3$ ) was tested. Two flexural cracks (cracks 1 and 2) appeared at the midspan of the beam (Fig. 5). As Beam 100-6.5 continued deflecting, additional shear cracks (cracks 6 and 7) and flexure-shear cracks (cracks 3-5) appeared in the beam. It was observed that the flexure-shear cracks appeared after the shear cracks in Beam 100-6.5. At $t=25 \mathrm{~ms}$, the beam reached its maximum midspan deflection and the cracks reached the maximum widths. Therefore, the failure mode for this beam was considered as flexure-shear. The post-impact damage of Beam 100-6.5 is presented in Fig. 5. It can be observed that the damage at the impact zone exposed the GFRP stirrups and longitudinal bars at some locations. The residual load-carrying capacity of Beam 100-6.5 was found to be $144 \mathrm{kN}$, which was $80 \%$ of the load-carrying capacity of the control beam. This indicates that the damage of Beam 100-6.5 could be considered as medium.

For the last test of Group 2 beams, Beam 75-6.5 (spacing of stirrups of $D / 4$ ) was tested. Fig. 5 presents the flexural cracks (cracks 1 and 2) and shear cracks (crack 3) in Beam 75-6.5 during the initial inertia response of the beam. As Beam 75-6.5 continued deflecting, additional shear cracks (crack 5) and flexure-shear cracks (cracks 4 and 6) appeared. It was observed that the flexure-shear cracks appeared after the shear cracks in Beam 75-6.5. This shows that Beam 75-6.5 with higher shear capacity than Beams 100-6.5 and 150-6.5 was capable of resisting the development of shear-plug damage mechanism. At $t=25 \mathrm{~ms}$, the beam reached its maximum midspan deflection and the cracks reached their maximum widths. The flexural cracks were more dominant than the shear cracks and had larger widths. The GFRP stirrups and longitudinal bars were exposed after the impact. The 
302

303

304

305

306

307

308

309

310

311

312

313

314

315

316

317

residual capacity of Beam 75-6.5 was measured by conducting a three-point quasi-static loads test on the beam after impact. The residual load-carrying capacity of Beam 75-6.5 was $164 \mathrm{kN}$ which is $91 \%$ of the load-carrying capacity of the control beam which could be considered as minor damage.

It was observed for Group 2 beams that an increase in the shear capacity led to the transition of the damage mechanisms from shear to flexure-shear which was consistent with the observed damage mechanisms of Group 1 beams. Large shear cracks were observed in beams with lower shear capacity (Beam 150-6.5), whereas Beam 75-6.5 with higher shear capacity did not experience severe shear cracking. The post-impact damage of the Beam 150-6.5 (spacing of stirrups of $D / 2$ ) was severe, whereas the damage of Beams 100-6.5 (stirrup spacing $D / 3$ ) and 75-6.5 (stirrup spacing $D / 4$ ) was medium and minor, respectively.

\section{Group 3 beams}

The impact energy was doubled for Group 3 beams compared to Group 1 beams which produced an impact velocity of $7.5 \mathrm{~m} / \mathrm{s}$. Similar to Groups 1 and 2, the first test was carried out for a beam with a spacing of stirrups $D / 2$, Beam 150-7.5, followed by Beam 100-7.5 (stirrup spacing $D / 3$ ), and then Beam 75-7.5 (stirrup spacing $D / 4$ ). During the inertia stage of impact loading for Beam 150-7.5, minor flexural cracks (crack 1) appeared at the midspan of the beam (Fig. 6). As Beam 150-7.5 continued deflecting, some of the flexural cracks transitioned into flexure-shear cracks (crack 3). Moreover, additional flexural cracks (crack 2) and large shear cracks (cracks 4-7) were formed. Beam 150-7.5 continued deflecting until the GFRP bars ruptured in tension. The beam did not rebound. The image of Beam 150-7.5 at $t=26 \mathrm{~ms}$ is presented although Beam 150-7.5 did not experience a maximum midspan deflection. The local damage of Beam 150-7.5 exposed the stirrups and the GFRP bars. The residual capacity of Beam 150-7.5 was assumed as zero due to rupture of the GFRP bars.

Due to technical difficulties, the high-speed video of Beam 100-7.5 was not captured. Upon analyzing the impact load and midspan deflection data, it was observed that Beam 100-7.5 reached the maximum midspan deflection after $26 \mathrm{~ms}$ of the impact. The value of the maximum midspan 
deflection was $90.6 \mathrm{~mm}$. The beam then rebounded to its initial position at $t=58 \mathrm{~ms}$. The concrete

cover was damaged and the GFRP stirrups and longitudinal bars were exposed. The residual deflection measured in Beam 100-7.5 was $19 \mathrm{~mm}$ which was $21 \%$ of the maximum midspan deflection. The residual capacity of Beam 100-7.5 was assumed as zero due to the partial rupture of the GFRP bars in tension and the high residual deflection.

The final impact loading test was carried out for Beam 75-7.5 (spacing of stirrups of $D / 4$ ). During the inertia loading phase, a shear crack (crack 1) appeared on Beam 75-7.5 (Fig. 6). As the beam continued deflecting, several flexure-shear cracks (cracks 4, 6, and 7), flexural cracks (cracks 2 and 3), and shear cracks (crack 5) appeared in the beam. At $t=26 \mathrm{~ms}$, the beam reached its maximum midspan deflection. The flexural and shear cracks were not as dominant as the flexure-shear cracks (cracks 4 and 7). This can be attributed to the large shear capacity of Beam 75-7.5 that resisted the development of the shear-plug mechanism in the beam. Moreover, it was observed that although the first crack to appear (crack 1) was a shear crack, the width of this crack did not significantly increase and was minor compared to the flexure-shear cracks. Beam 75-7.5 then rebounded to its initial position and the impactor bounced on the beam a few times which caused one of the GFRP bars in tension to fully rupture (Fig. 6). The residual capacity of Beam 75-7.5 was assumed to zero due to the rupture of the GFRP bar.

It was observed that all beams belonging to Group 3 experienced catastrophic failure due to GFRP bar rupture. Beams with lower shear capacities (Beam 150-7.5) failed without the beam rebounding to its initial position. Beams with higher shear capacities (Beams 100-7.5 and 75-7.5) failed after the impactor bounced on the beams. Moreover, dominant shear cracks were observed in beams with lower shear capacity (Beam 150-7.5), whereas Beam 75-7.5 with higher shear capacity experienced a flexure-shear failure.

Under impact loads, the majority of the input impact energy is transformed into kinetic energy during the vibration [4]. The remaining energy is dissipated by concrete cracking, damage, and 
352

353

354

355

356

357

358

359

360 361 in Eq. 1:

362

permanent deformation $[4,6,13]$. In this study, the residual midspan deflection of GFRP-RC beams subjected to high-intensity low-velocity impact loads was relatively small (under 20\%) when the GFRP bars did not rupture. However, the GFRP-RC beams that experienced severe local damage (Group 2 and Group 3 beams) may not be repairable.

\subsubsection{Dynamic equilibrium of applied forces}

The dynamic forces during the impact were the impact force, reaction force, and inertia force. According to Saatci and Vecchio [4], the impact force, at a certain instant, equals the sum of the reaction force and the inertia of the beam. The inertia of the beam is calculated as the integral of the mass per unit length of the beam multiplied by the acceleration of the beam over its length, as shown

$$
\int_{0}^{L} \bar{m} \ddot{u}(x, t) d x+R(t)=I(t)
$$

where $L$ is the length of the beam, $\bar{m}$ is the mass per unit length of the beam, $\ddot{u}$ is the acceleration of a particular point on the beam, $R$ is the total reaction force, and $I$ is the impact force. In this experiment, the impact and reaction forces were recorded using load cells, and the accelerations were recorded using accelerometers attached externally to the beams. The change in the acceleration between two adjacent accelerometers was assumed linear. The distributions of the accelerometers and forces are presented in Fig. 7. Six accelerometers were used, which were spaced at $200 \mathrm{~mm}$ on one half of the beam starting at the midspan and ending at the end of the overhang of the beam. The accelerations at the supports were assumed to be zero. The capacity of the accelerometers used was $1000 \mathrm{~g}$, where $\mathrm{g}$ is the gravitational acceleration.

It was observed that regardless of the amount of shear reinforcement, the duration of the initial triangular pulse was almost $2 \mathrm{~ms}$. The second pulse started after $5 \mathrm{~ms}$ of the impact and fluctuated until the end of the impact. It was also observed that when the impact velocity increased, the maximum impact load increased as well. Therefore, the shear reinforcement had no influence on the impact force for beams belonging to the same group. The reaction force, on the other hand, started 
after $5 \mathrm{~ms}$ of the impact and fluctuated until the end of the impact. It was observed that the delay between the impact and reaction forces was around 5 milliseconds. This delay is due to the time it took for the stress wave to propagate from the impact zone to the supports.

\section{Analysis of the dynamic shear force}

The dynamic shear force distribution of a GFRP-RC beam under impact load is different from the shear distribution under quasi-static loads. In order to measure the dynamic shear force in the beams, the data from the accelerometers were analyzed. The dynamic shear force over the duration of the impact was plotted using the static equilibrium of the dynamic forces (inertia, impact, and reaction) and Eq. 1. The maximum measured shear forces for every beam are presented in Table 3. It was observed from Table 3 that when the experimental shear force was significantly larger than the shear capacity predicted by ACI [30], the failure mode was shear.

An analysis was carried out over the first $10 \mathrm{~ms}$ of impact to determine the instant at which the dynamic shear force peaked. It was found that the maximum dynamic shear force was recorded after $1 \mathrm{~ms}$ of the impact (when the impact force peaked) before the shear force decreased to a minimum after $5 \mathrm{~ms}$ (when the reaction force was present). This observation was similar to the findings of Zhao et al. [9]. It was reported in Zhao et al. [9] that the maximum dynamic shear force was recorded after $1 \mathrm{~ms}$ (maximum impact force) of the impact and the minimum dynamic shear force was recorded after $5 \mathrm{~ms}$ of the impact. This can be explained by the impact force reaching its peak after $1 \mathrm{~ms}$ of the impact, where the forces acting during the first millisecond of impact were the impact force and the inertia force. The reaction forces were not activated during the first millisecond of impact due to the stress waves not reaching the support. The maximum dynamic shear force was directly correlated with the maximum impact force. The maximum dynamic shear force increased during the first millisecond of impact similar to the impact force, then decreased with the impact force. After $5 \mathrm{~ms}$ of the impact, the reaction force was activated and the forces present were the impact force, inertia force, and reaction force. The dynamic shear force diagram of Beam 75-5.5 over the first $5 \mathrm{~ms}$ of 
impact is presented in Fig. 8. It can be observed that the shape of the shear force was gradually

402 transitioning from dynamic shear to quasi-static shear over the first $5 \mathrm{~ms}$ of impact. This showed that

403 the shear cracks were generated within the first $5 \mathrm{~ms}$ of impact. The failure mode of the beams was

404 then determined by comparing the shear capacity of the beam calculated as per ACI [30] with the

405 maximum measured shear force. If the maximum shear force measured in the beam was larger than

406 the shear capacity, the failure mode was considered to be shear failure. The dynamic shear force

407 diagrams, for the first millisecond of impact, of the beams tested is presented in Fig. 9. The dynamic

408 shear force diagrams after $5 \mathrm{~ms}$ of impact are presented in Fig. 10. It was also observed after analyzing

409 the shear cracks in the beam that the beams predicted to fail in shear according to ACI [30] failed in

410 shear.

\section{5. Design recommendations based on impact testing of GFRP-RC beams}

4125.1 Validation of the damage mechanisms based on the code provisions

413 According to ACI [30], the design of shear reinforcement for a GFRP-RC beam is similar to that 414 of a Steel-RC beam. However, the mechanical properties of the GFRP bars affect the shear strength 415 and should be taken into account. The nominal shear strength at a section $\left(V_{n}\right)$, presented in Eq. 2, is 416 the sum of the nominal shear strength provided by concrete $\left(V_{c}\right)$ and the shear resistance provided by 417 the GFRP shear reinforcement $\left(V_{f}\right)$. The shear capacities for the nine beams calculated by ACI [30] 418 were presented in Table 3.

$$
V_{n}=V_{c}+V_{f}
$$

419 The nominal shear strength provided by concrete is calculated by Eq. 3 (SI units)

$$
V_{c}=\frac{2}{5} \sqrt{f_{c}^{\prime}} b(k d)
$$


where $f_{c}^{\prime}$ is the compressive strength of concrete (in MPa), $b$ is the width of the beam (in mm), $k$ is the ratio of depth of neutral axis to reinforcement depth presented in Eq. 4, and $d$ is the distance from extreme compression fiber to centroid of tensile longitudinal bars (in $\mathrm{mm}$ ).

$$
k=\sqrt{2 \rho_{f} n_{f}+\left(\rho_{f} n_{f}\right)^{2}}-\rho_{f} n_{f}
$$

where $\rho_{f}$ is the longitudinal reinforcement ratio and $n_{f}$ is the modular ratio calculated by Eq. 5

$$
n_{f}=\frac{E_{f}}{E_{c}}
$$

where $E_{f}$ is the modulus of elasticity of the GFRP bars and $E_{c}$ is the modulus of elasticity of concrete (calculated as $5700 \sqrt{f_{c}^{\prime}}$ for $f_{c}^{\prime}$ in psi or $4700 \sqrt{f_{c}^{\prime}}$ for $f_{c}^{\prime}$ in MPa).

The contribution of the GFRP shear reinforcement is calculated by Eq. 6

$$
V_{f}=\frac{A_{f} f_{f} d}{s}
$$

where $f_{f}$ is the tensile strength of the shear reinforcement (in MPa), $s$ is the center-to-center spacing of shear stirrups (in $\mathrm{mm}$ ), and $A_{f}$ is the area of shear reinforcement in the spacing $s$ (in $\mathrm{mm}^{2}$ ).

\subsection{Recommendations based on experimental observations}

The input parameters of this experimental program were the shear reinforcement and the impact velocity. In this study, a spacing of $D / 2(150 \mathrm{~mm}), D / 3(100 \mathrm{~mm})$, and $D / 4(75 \mathrm{~mm})$ were chosen between the stirrups. The three impact energies used were 8684 Joules, 13026 Joules and 17368 Joules which were multiples of the energy absorption capacity of the control beam.

In terms of the residual deflections of the beams impacted with an impact energy equivalent of $1.0 E$, it was observed that a decrease in the spacing of the shear reinforcement to $D / 3$ led to a $40 \%$ decrease in the residual deflection (compared to $D / 2$ spacing). Moreover, a decrease in the spacing of the shear reinforcement to $\mathrm{D} / 4$ led to a $60 \%$ decrease in the residual deflection. When the impact energy was increased to $1.5 E$, it was observed that a decrease in the spacing of the shear reinforcement 
to $D / 3$ led to a $6 \%$ decrease in the residual deflection. Moreover, a decrease in the spacing of the shear

440 reinforcement to $\mathrm{D} / 4$ led to an $18 \%$ decrease in the residual deflection. When the impact energy was

441 increased to $2.0 E$, it was observed that all beams failed by GFRP bar rupture. This observation

442 suggests that GFRP-RC beams may not be able to sustain an overload caused by impact energy

443 exceeding 1.5 times the quasi-static energy absorption capacity without catastrophic collapse.

444 In terms of the residual capacities of the beams impacted with an impact energy equivalent to $1.0 E$,

445 it was observed that when the spacing of the shear reinforcement decreased to $D / 3$, the residual

446 capacity of the beam was $92 \%$. Moreover, when the spacing of the shear reinforcement decreased to

$447 \mathrm{D} / 4$, the residual capacity of the beam was $97 \%$. The residual capacity of the beam with a stirrup

448 spacing of $D / 2$ was $85 \%$. When the impact energy was increased to $1.5 E$ intensity, it was observed

449 that when the spacing of the shear reinforcement decreased to $D / 3$, the residual capacity of the beam

450 was $80 \%$. Moreover, when the spacing of the shear reinforcement decreased to $D / 4$, the residual

451 capacity of the beam was $91 \%$. The residual capacity of the beam with a stirrup spacing of $D / 2$ was

$452 \quad 73 \%$.

453 Therefore, decreasing the spacing of the shear reinforcement to $D / 3$ had a significant influence on

454 GFRP-RC beams in terms of the residual deflection and residual capacities under impact energies

455 close to the quasi-static energy absorption capacity. However, when the impact energy increases up

456 to the level of $2.0 E$, decreasing the spacing of the shear reinforcement to $\mathrm{D} / 4$ had a more significant

457 influence on the residual deflections and residual capacities of the GFRP-RC beams. It is noted that

458 more research is required to study the effect of the decreasing the stirrups spacing in certain locations

459 (in the impact zone only or in the shear span) on the damage behavior of GFRP-RC beams and the

460 residual capacity of the beams under impact loads.

461 Fig. 11 presents the residual capacities of the beams with different shear capacities. The damage 462 zones were also presented in Fig. 11. Based on the discussion above, it is recommended to use shear 463 reinforcement spacing of $D / 3$ to transform the shear failure into a flexure-shear failure for beams 
464

465

466

467

468

under impact energies in the vicinity of their quasi-static energy absorption capacities. However, under higher impact energies (impact energies close to the intensity of $2.0 E$ ), the beams might still fail in shear. Therefore, it is recommended to use shear reinforcement spacing of $D / 4$ to resist the shear failure and transform the failure into flexural failure or flexure-shear failure even when the impact energy is twice the quasi-static energy absorption capacity of the beams.

Based on the above results, it is recommended for designers to use the above recommendations to design or check a GFRP-RC beam section under a specified input impact energy. To check if an existing GFRP-RC beam can resist a specified impact load, the section capacity should be calculated first. The section capacity can be calculated using existing design codes [30, 32]. For example, using ACI [30] recommendations, the section capacity can be calculated for an over-reinforced or underreinforced section using equations 7.2.2a and 7.2.2f, respectively. After the section capacity is calculated, the ultimate load and corresponding midspan deflection (section 7.3.2.3) can be calculated. Therefore, plotting the load-midspan deflection allows for the calculation of the maximum quasi-static energy absorption capacity $\left(E_{s, \max }\right)$ of the beam. If $E_{s, \max }$ is larger than 1.5 times the input impact energy $E$, then the post-impact residual capacity of the beam would be dependent on its shear capacity.

If a new GFRP-RC beam were to be designed, similar steps should be followed. The minimum quasi-static energy absorption capacity $\left(E_{s, \min }\right)$ should be larger than 1.5 times the input impact energy $E$, or the following design condition should be satisfied, $E_{s, \min } \geq 1.5 E$. To calculate $E_{s, \min }$, both the ultimate load and corresponding midspan deflection need to be calculated. The ultimate load should be assumed first by trial and error and the corresponding midspan deflection should be calculated based on the ultimate load. The quasi-static energy absorption capacity of a GFRP-RC beam can be calculated as per design code recommendations. After several iterations (if required), when the calculated $E_{s, \min }$ is found, the ultimate load can then be used to design the section. 
Therefore, the section dimensions, compressive strength of concrete, and GFRP bar reinforcement can be designed to resist high-intensity low-velocity impact loads.

\section{Conclusions}

In this paper, the overload damage mechanisms of nine GFRP-RC beams were investigated by conducting a series of impact loads tests. A well-instrumented experimental program was carried out to investigate the influence of shear capacity and impact velocity on the behavior of GFRP-RC beams under high-intensity low-velocity impact loads. After impact, the beams were tested under quasistatic monotonically increasing loads to determine the residual capacities of these beams. The following conclusions were drawn:

1. The shear capacities of the GFRP beams significantly influenced the failure modes of the beams under high-intensity low-velocity impact loads. Beams with higher shear capacities failed in flexure and flexure-shear, whereas beams with lower shear capacities developed shear-plug type of failure.

2. As the impact velocity increased, all beams regardless of their shear capacities experienced higher levels of local damage and post-impact cracks.

3. During the first $5 \mathrm{~ms}$ of the impact, the shear force transitioned from a dynamic shear force at the center of the beam to a quasi-static shear force. The shear-plug cracks observed on all beams can be explained using the dynamic shear force diagrams of the beams which are influenced by the inertia resistance of the beams.

4. The maximum input impact energy the beams were able to resist was 1.5 times the quasistatic energy absorption capacity. An input impact energy higher than that led to a catastrophic failure of the beams regardless of the shear capacity.

5. It was observed that increasing the shear capacity of a GFRP-RC beam led to smaller residual deflections and higher residual capacities. To resist impact loads, it is recommended to use a spacing of the shear reinforcement of $D / 3$ for beams subjected to impact energies similar to the quasi-static 
energy absorption capacity and a spacing of $D / 4$ for beams that could be subjected to impact energies

514 up to 1.5 times the quasi-static energy absorption capacity.

5156 . Based on the experimental observations and existing design codes, design recommendations

516 were provided to design a GFRP-RC section to resist a specified input impact load.

\section{Acknowledgments}

518 The authors express their gratitude to the University of Wollongong for providing the funding and

519 facilities for the experimental work and the authors thank the technical officers for their contributions

520 in the experiments. The authors also express their appreciation to Ian Cumming (Director IRC Pty

521 Ltd) and Pultron (www.pultron.com) for providing the GFRP bars used in the experimental program.

\section{References}

523 [1] Sharma H, Hurlebaus S, Gardoni P. Performance-based response evaluation of reinforced concrete columns subject to vehicle impact. International Journal of Impact Engineering. 2012;43:52-62.

[2] Fujikake K, Senga T, Ueda N, Ohno T, Katagiri M. Study on Impact Response of Reactive Powder Concrete Beam and Its Analytical Model. Journal of Advanced Concrete Technology. 2006;4:99-108.

[3] May IM, Chin YM. Reinforced concrete beams under drop-weight impact loads. Computers and Concrete. 2009;3:79-90.

[4] Saatci S, Vecchio FJ. Effects of Shear Mechanisms on Impact Behavior of Reinforced Concrete Beams. ACI Structural Journal. 2009;106:78-86.

[5] Adhikary SD, Li B, Fujikake K. Strength and behavior in shear of reinforced concrete deep beams under dynamic loading conditions. Nuclear Engineering and Design. 2013;259:14-28.

[6] Adhikary SD, Li B, Fujikake K. Low Velocity Impact Response of Reinforced Concrete Beams: Experimental and Numerical Investigation. International Journal of Protective Structures. 2015;6:81-111.

[7] Pham TM, Hao H. Prediction of the impact force on reinforced concrete beams from a drop weight. Advances in Structural Engineering. 2016;19:1710-22.

[8] Pham TM, Hao H. Review of concrete structures strengthened with FRP against impact loading. Structures: Elsevier; 2016. p. 59-70.

[9] Zhao DB, Yi WJ, Kunnath SK. Shear Mechanisms in Reinforced Concrete Beams under Impact Loading. Journal of Structural Engineering. 2017;143:04017089.

[10] Pham TM, Hao H. Plastic hinges and inertia forces in RC beams under impact loads. International Journal of Impact Engineering. 2017;103:1-11.

[11] Guo J, Cai J, Chen W. Inertial effect on RC beam subjected to impact loads. International Journal of Structural Stability and Dynamics. 2017;17:1750053.

[12] Anil Ö, Durucan C, Erdem RT, Yorgancilar MA. Experimental and numerical investigation of reinforced concrete beams with variable material properties under impact loading. Construction and Building Materials. 2016;125:94-104.

[13] Fujikake K, Li B, Soeun S. Impact Response of Reinforced Concrete Beam and Its Analytical Evaluation. Journal of Structural Engineering. 2009;135:938-50.

[14] Yi WJ, Zhao DB, Kunnath SK. Simplified Approach for Assessing Shear Resistance of Reinforced Concrete Beams under Impact Loads. ACI Structural Journal. 2016;113:747-56.

[15] Kishi N, Mikami H, Matsuoka KG, Ando T. Impact behavior of shear-failure-type RC beams without shear rebar. International Journal of Impact Engineering. 2002;27:955-68. 
[16] Adhikary SD, Li B, Fujikake K. Residual resistance of impact-damaged reinforced concrete beams. Magazine of Concrete Research. 2015;67:364-78.

[17] Adhikary SD, Li B, Fujikake K. Parametric study of RC beams under a wide range of loading rates. Proceedings of the Institution of Civil Engineers - Structures and Buildings. 2015;168:729-46.

[18] Adhikary SD, Li B, Fujikake K. Effects of high loading rate on reinforced concrete beams. 2014.

[19] Karim H, Sheikh MN, Hadi MN. Axial load-axial deformation behaviour of circular concrete columns reinforced with GFRP bars and helices. Construction and Building Materials. 2016;112:1147-57.

[20] Hasan HA, Sheikh MN, Hadi MN. Performance evaluation of high strength concrete and steel fibre high strength concrete columns reinforced with GFRP bars and helices. Construction and Building Materials. 2017; 134:297-310.

[21] Focacci F, Nanni A, Bakis CE. Local bond-slip relationship for FRP reinforcement in concrete. Journal of Composites for Construction. 2000;4:24-31.

[22] Gravina RJ, Smith ST. Flexural behaviour of indeterminate concrete beams reinforced with FRP bars. Engineering Structures. 2008;30:2370-80.

[23] Malvar LJ. Tensile and Bond Properties of Gfrp Reinforcing Bars. ACI Materials Journal. 1995;92:27685.

[24] Tighiouart B, Benmokrane B, Gao D. Investigation of bond in concrete member with fibre reinforced polymer (FRP) bars. Construction and Building Materials. 1998;12:453-62.

[25] Fang Z, Zhang K, Tu B. Experimental investigation of a bond-type anchorage system for multiple FRP tendons. Engineering Structures. 2013;57:364-73.

[26] Benmokrane B, Chaallal O, Masmoudi R. Glass fibre reinforced plastic (GFRP) rebars for concrete structures. Construction and Building Materials. 1995;9:353-64.

[27] Goldston MW, Remennikov A, Sheikh MN. Flexural behaviour of GFRP reinforced high strength and ultra high strength concrete beams. Construction and Building Materials. 2017;131:606-17.

[28] Rolland A, Quiertant M, Khadour A, Chataigner S, Benzarti K, Argoul P. Experimental investigations on the bond behavior between concrete and FRP reinforcing bars. Construction and Building Materials. 2018;173:136-48.

[29] Saleh N, Ashour A, Lam D, Sheehan T. Experimental investigation of bond behaviour of two common GFRP bar types in high-Strength concrete. Construction and Building Materials. 2019;201:610-22.

[30] ACI. Guide for the Design and Construction of Structural Concrete Reinforced with Fiber-Reinforced Polymer (FRP) Bars (ACI 440.1R-15). Farmington Hills, MI 48331: American Concrete Institute; 2015.

[31] ACI. Guide for the Design and Construction of Structural Concrete Reinforced with Fiber-Reinforced Polymer (FRP) Bars (ACI 440.1R-06). Farmington Hills, Michigan, USA: American Concrete Institute; 2006. [32] Australia S. Methods of Testing Concrete - Compressive Strength Tests - Concrete, Mortar and Grout Specimens. AS10129. Sydney, New South Wales, Australia: Standards Australia; 2014.

[33] FIB F. Model code for concrete structures 2010. 2013.

[34] ISIS. Reinforcing concrete structures with fibre reinforced polymers (FRPs). Design Manual 3 ISIS-M0301, The Canadian Network of Centres of Excellence on Intelligent Sensing for Innovative Structures, ISIS Canada, University of Manitoba, Winnipeg, Man. 2007.

[35] Adam MA, Said M, Mahmoud AA, Shanour AS. Analytical and experimental flexural behavior of concrete beams reinforced with glass fiber reinforced polymers bars. Construction and Building Materials. 2015;84:354-66.

[36] Ashour AF. Flexural and shear capacities of concrete beams reinforced with GFRP bars. Construction and Building Materials. 2006;20:1005-15.

[37] Benmokrane B, Chaallal O, Masmoudi R. Flexural response of concrete beams reinforced with FRP reinforcing bars. ACI Structural Journal. 1996;93:46-55.

[38] El-Nemr A, Ahmed EA, Benmokrane B. Flexural Behavior and Serviceability of Normal- and HighStrength Concrete Beams Reinforced with Glass Fiber-Reinforced Polymer Bars. ACI Structural Journal. 2013;110:1077-87.

[39] Saleh Z, Goldston M, Remennikov AM, Sheikh MN. Flexural design of GFRP bar reinforced concrete beams: An appraisal of code recommendations. Journal of Building Engineering. 2019:100794.

[40] Saleh Z, Sheikh MN, Remennikov AM, Basu A. Numerical investigations on the flexural behavior of GFRP-RC beams under monotonic loads. Structures. 2019;20:255-67.

[41] Goldston M, Remennikov A, Sheikh MN. Experimental investigation of the behaviour of concrete beams reinforced with GFRP bars under static and impact loading. Engineering Structures. 2016;113:220-32. 
609 [42] Saleh Z, Sheikh MN, Remennikov AM, Basu A. Numerical Analysis of Behavior of Glass Fiber610 Reinforced Polymer Bar-Reinforced Concrete Beams under Impact Loads. ACI Structural Journal. $6112019 ; 116: 151-60$.

612 [43] Goldston MW, Remennikov A, Saleh Z, Sheikh MN. Experimental investigations on the behavior of 613 GFRP bar reinforced HSC and UHSC beams under static and impact loading. Structures. 2019;22:109-23.

614 [44] Adhikary SD, Li B, Fujikake K. Dynamic behavior of reinforced concrete beams under varying rates of 615 concentrated loading. International Journal of Impact Engineering. 2012;47:24-38.

616 [45] Adhikary SD, Li B, Fujikake K. Residual resistance of impact-damaged reinforced concrete beams. 2014.

617 [46] Hughes B, AI-Dafiry H. Impact energy absorption at contact zone and supports of reinforced plain and 618 fibrous concrete beams. Construction and Building Materials. 1995;9:239-44.

619 


\section{Tables}

Table 1

Details of the tested beams

\begin{tabular}{|c|c|c|c|c|c|c|}
\hline \multirow[b]{2}{*}{$\begin{array}{l}\text { Beam } \\
\text { Group }\end{array}$} & \multirow[b]{2}{*}{ Beam name } & \multirow[b]{2}{*}{$\begin{array}{l}\text { Dimensions } \\
\text { of beam } \\
(\mathrm{mm})\end{array}$} & \multirow{2}{*}{$\begin{array}{l}\text { Compressive } \\
\text { strength of } \\
\text { concrete } \\
(\mathrm{MPa})\end{array}$} & \multirow[b]{2}{*}{$\begin{array}{l}\text { Longitudinal } \\
\text { reinforcement } \\
\text { (mm) }\end{array}$} & \multicolumn{2}{|c|}{ Transverse reinforcement } \\
\hline & & & & & $\begin{array}{c}\text { Bar } \\
\text { diameter } \\
(\mathrm{mm})\end{array}$ & $\begin{array}{l}\text { Spacing } \\
\text { (mm) }\end{array}$ \\
\hline $\mathrm{C}$ & $\begin{array}{c}\text { Control } \\
\text { beam }\end{array}$ & \multirow{10}{*}{$\begin{array}{l}200 \text { (Width) } \\
300 \text { (Depth) }\end{array}$} & \multirow{10}{*}{59.3} & \multirow{10}{*}{$\begin{array}{c}\text { Two } 16 \mathrm{~mm} \\
\text { bars (Tension) } \\
\text { Two } 16 \mathrm{~mm} \\
\text { bars } \\
\text { (Compression) }\end{array}$} & & 100 \\
\hline \multirow{3}{*}{1} & $75-5.5$ & & & & & 75 \\
\hline & $100-5.5$ & & & & & 100 \\
\hline & $150-5.5$ & & & & & 150 \\
\hline \multirow{3}{*}{2} & $75-6.5$ & & & & 12 & 75 \\
\hline & $100-6.5$ & & & & & 100 \\
\hline & $150-6.5$ & & & & & 150 \\
\hline \multirow{3}{*}{3} & $75-7.5$ & & & & & 75 \\
\hline & $100-7.5$ & & & & & 100 \\
\hline & $150-7.5$ & & & & & 150 \\
\hline
\end{tabular}


Table 2

Midspan deflection details of the tested beams

\begin{tabular}{|c|c|c|c|c|c|c|}
\hline $\begin{array}{l}\text { Beam } \\
\text { Group }\end{array}$ & $\begin{array}{l}\text { Beam } \\
\text { name }\end{array}$ & $\begin{array}{c}\text { Impact } \\
\text { velocity } \\
(\mathrm{m} / \mathrm{s})\end{array}$ & $\begin{array}{l}\text { Maximum } \\
\text { midspan } \\
\text { deflection } \\
(\mathrm{mm}) \\
\left(\Delta_{\max }\right)\end{array}$ & $\begin{array}{c}\text { Time at } \\
\text { maximum } \\
\text { midspan } \\
\text { deflection }(\mathrm{sec}) \\
\left(t_{\Delta_{\max }}\right)\end{array}$ & $\begin{array}{l}\text { Time at } \\
\text { final } \\
\text { position } \\
(\mathrm{sec}) \\
\left(t_{\text {final }}\right)\end{array}$ & $\begin{array}{c}\text { Residual } \\
\text { midspan } \\
\text { deflection } \\
(\mathrm{mm}) \\
\left(\Delta_{r e s}\right)\end{array}$ \\
\hline \multirow{3}{*}{1} & $75-5.5$ & \multirow{3}{*}{5.5} & 59.2 & 0.022 & 0.048 & 4 \\
\hline & $100-5.5$ & & 60.9 & 0.023 & 0.048 & 6 \\
\hline & $150-5.5$ & & 61.4 & 0.023 & 0.048 & 10 \\
\hline \multirow{3}{*}{2} & $75-6.5$ & \multirow{3}{*}{6.5} & 72.3 & 0.025 & 0.05 & 14 \\
\hline & $100-6.5$ & & 73.1 & 0.025 & 0.051 & 16 \\
\hline & $150-6.5$ & & 85.8 & 0.026 & 0.057 & 17 \\
\hline \multirow{3}{*}{3} & $75-7.5$ & \multirow{3}{*}{7.5} & 90.6 & 0.026 & 0.058 & 19 \\
\hline & $100-7.5$ & & 92.4 & 0.026 & 0.058 & 22 \\
\hline & $150-7.5$ & & $\mathrm{~N} / \mathrm{A}$ & N/A & N/A & N/A \\
\hline
\end{tabular}

*Note: $\Delta_{\text {max }}$ : maximum midspan deflection, $t_{\Delta_{\max }}$ : time at maximum midspan deflection, $t_{\text {final }}$ : time when the beam returned to its initial position, $\Delta_{\text {res }}$ : residual midspan deflection 
Table 3

Shear capacity of the tested beams

\begin{tabular}{|c|c|c|c|c|}
\hline $\begin{array}{c}\text { Beam } \\
\text { Group }\end{array}$ & Beam name & $\begin{array}{c}\text { Peak dynamic } \\
\text { shear force } \\
(\mathrm{kN})\end{array}$ & $\begin{array}{c}\text { Shear capacity } \\
\text { according to } \\
\text { ACI [30] } \\
(\mathrm{kN})\end{array}$ & Failure mode \\
\hline \multirow{4}{*}{1} & $75-5.5$ & 361 & 374 & Flexural failure \\
\cline { 2 - 5 } & $100-5.5$ & 365 & 286 & Shear failure \\
\cline { 2 - 5 } & $150-5.5$ & 371 & 198 & Shear failure \\
\hline \multirow{3}{*}{2} & $75-6.5$ & 402 & 374 & Flexure-shear failure \\
\cline { 2 - 5 } & $100-6.5$ & 401 & 286 & Flexure-shear failure \\
\cline { 2 - 5 } & $150-6.5$ & 410 & 198 & Shear failure \\
\hline \multirow{3}{*}{3} & $75-7.5$ & 457 & 374 & Shear failure \\
\cline { 2 - 5 } & $100-7.5$ & 435 & 286 & Shear failure \\
\cline { 2 - 5 } & $150-7.5$ & N/A & 198 & Shear failure \\
\hline
\end{tabular}




\section{Figures}

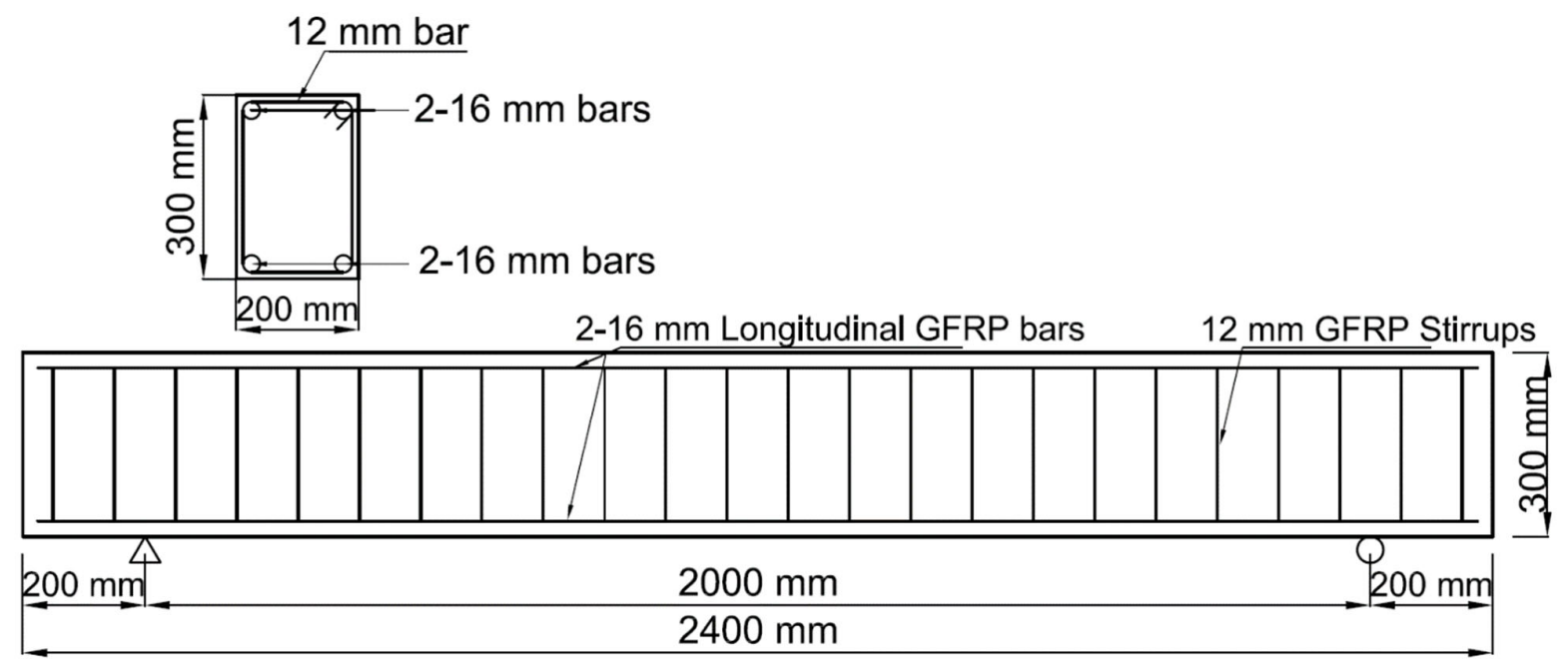

Fig. 1. Details of the tested GFRP-RC beams 


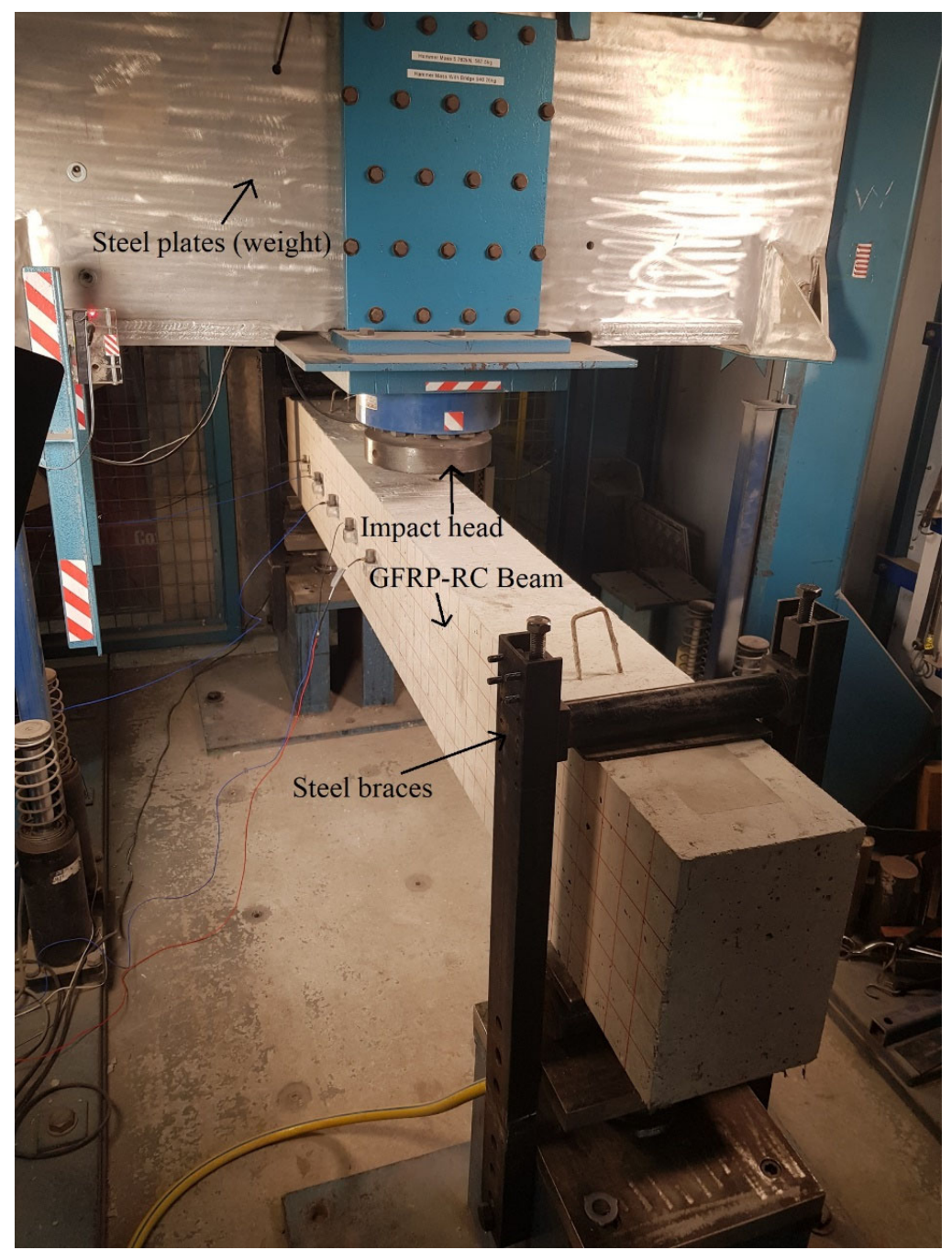

Fig. 2. Impact loads test 


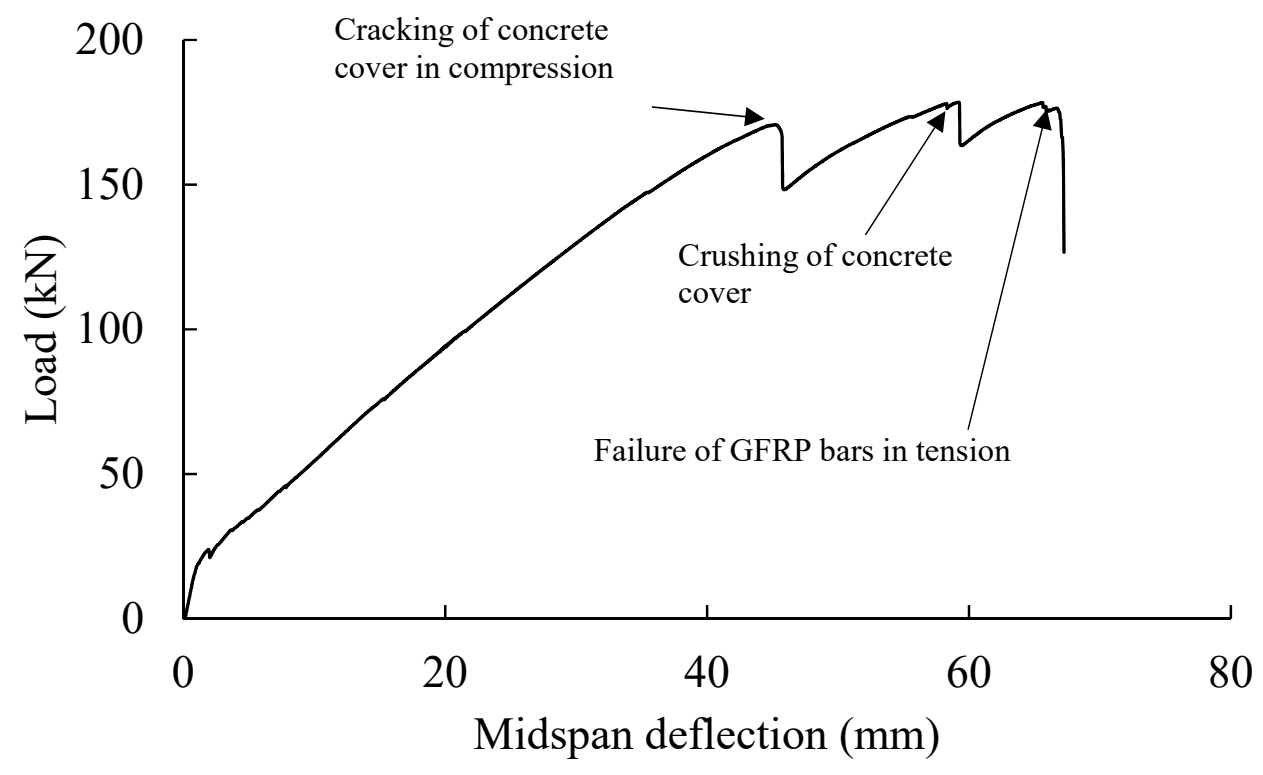

Fig. 3. Load-midspan deflection behavior of the control beam 


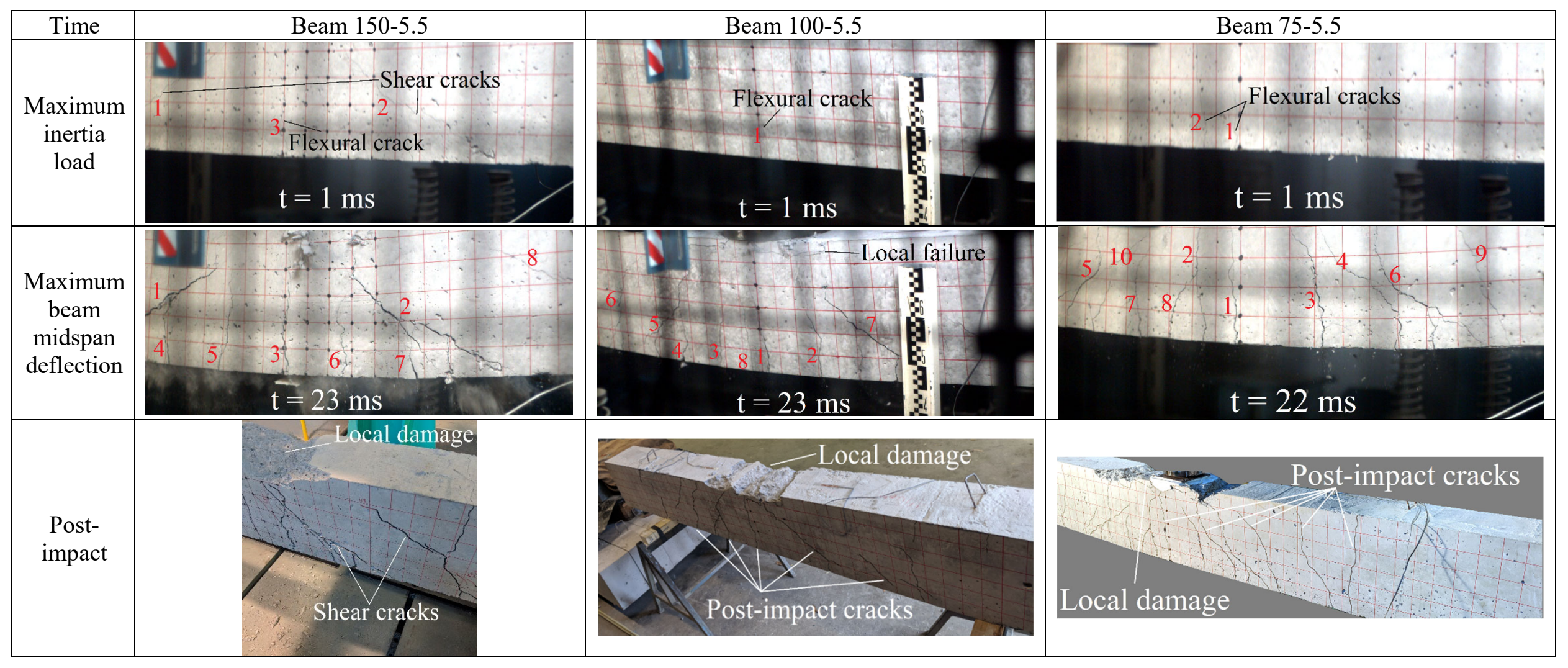

Fig. 4. Damage progression of Group 1 beams under impact loads 


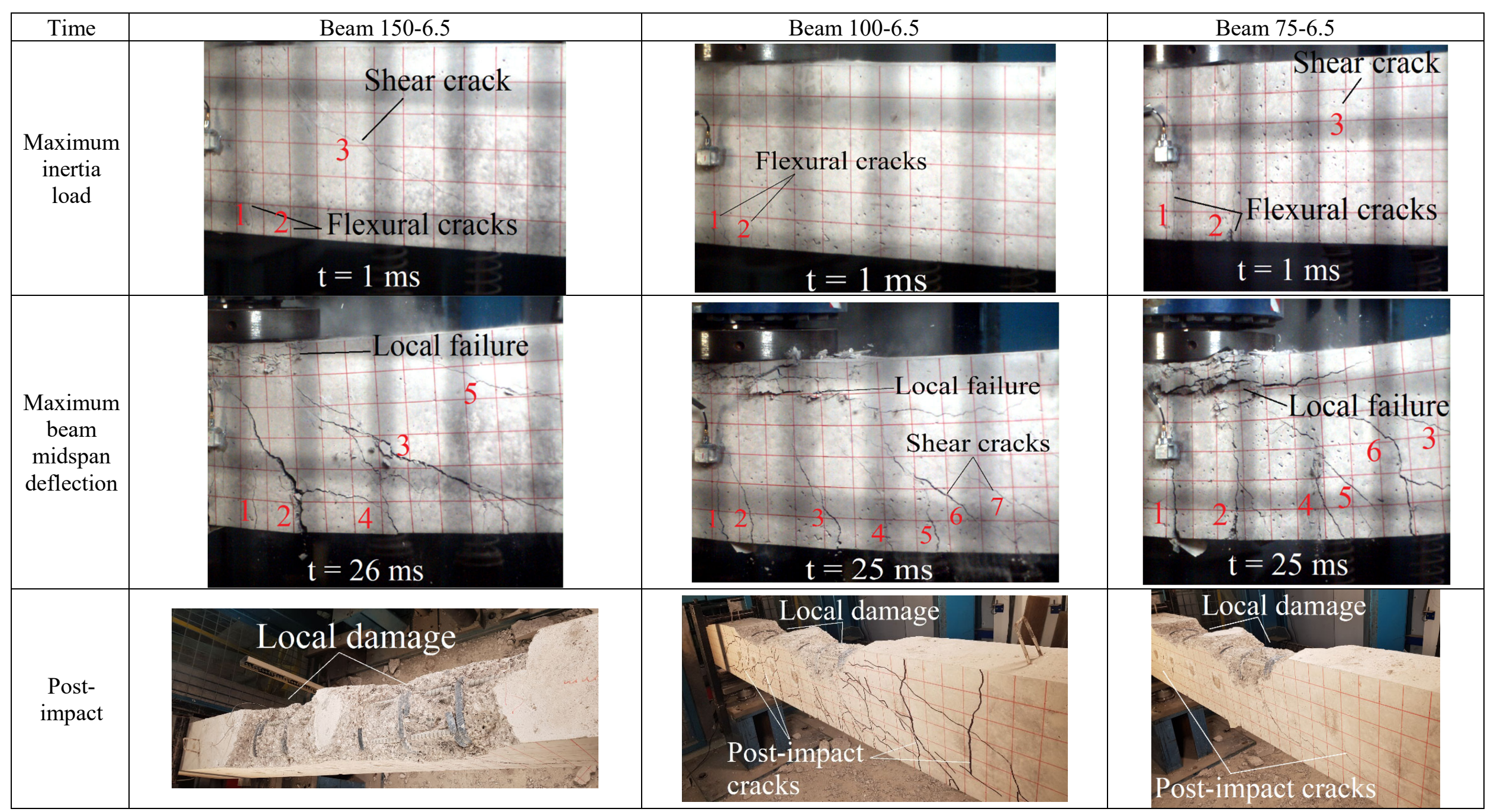

Fig. 5. Damage progression of Group 2 beams under impact loads (see Table 1) 


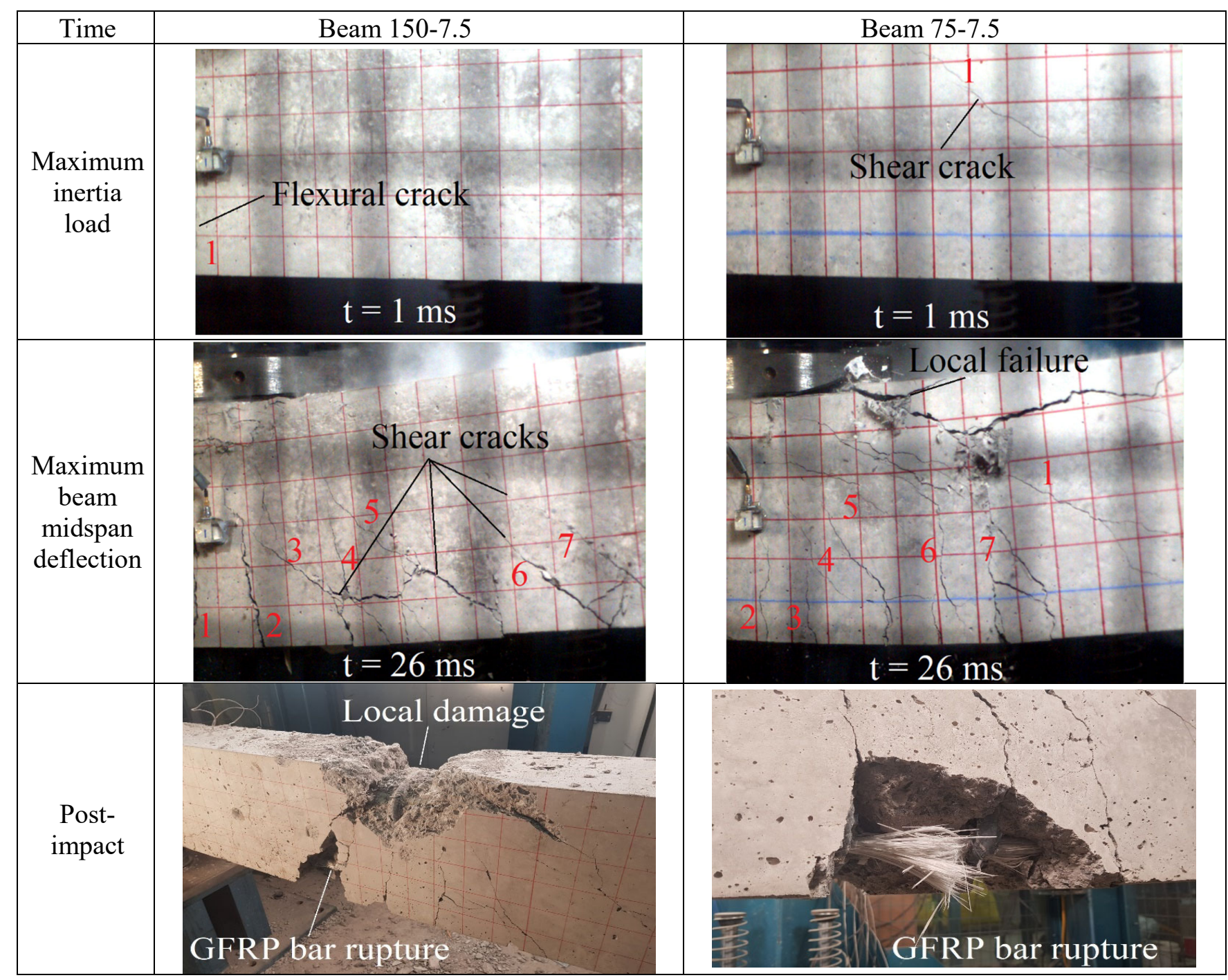

Fig. 6. Damage progression of Group 3 beams under impact loads (see Table 1) 


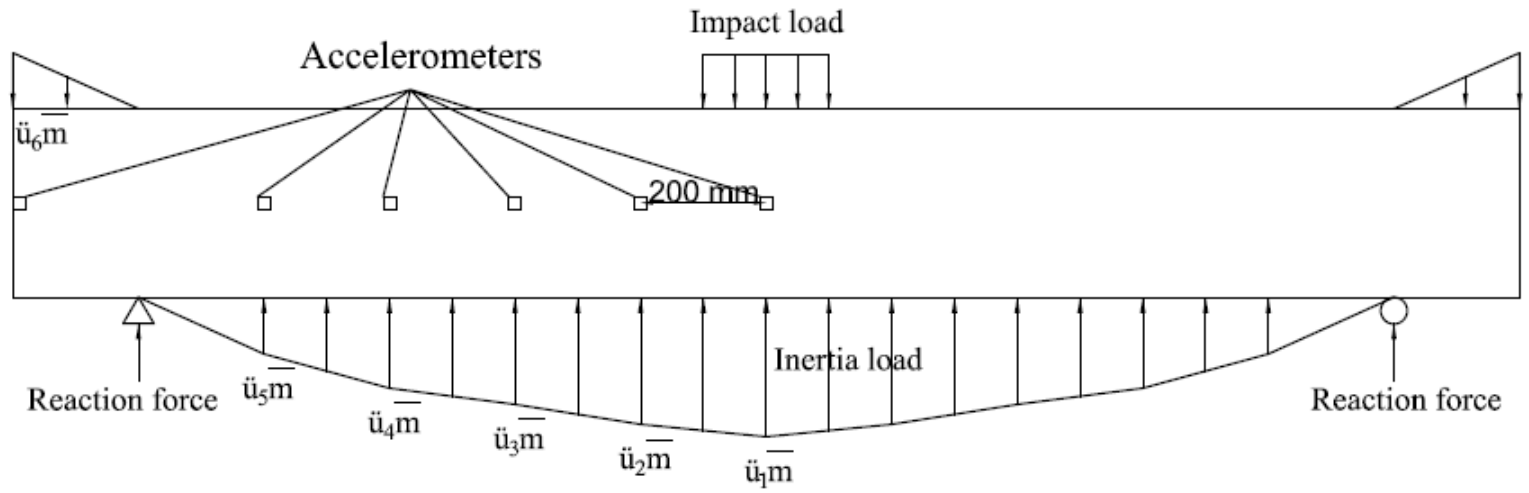

Fig. 7. Distribution of the accelerometers along the beam 


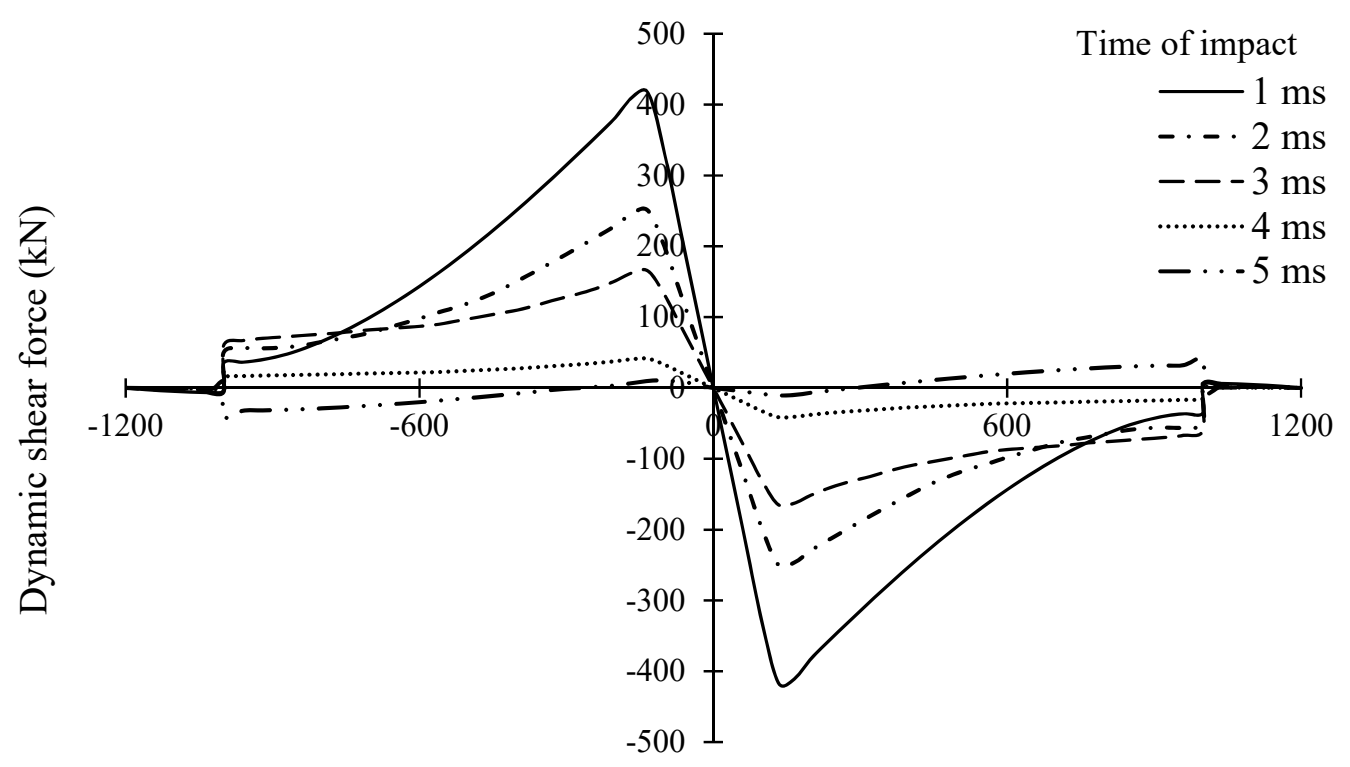

Position from the center of the beam (mm)

Fig. 8. Dynamic shear force diagram of Beam 75-5.5 over the first $5 \mathrm{~ms}$ of the impact 


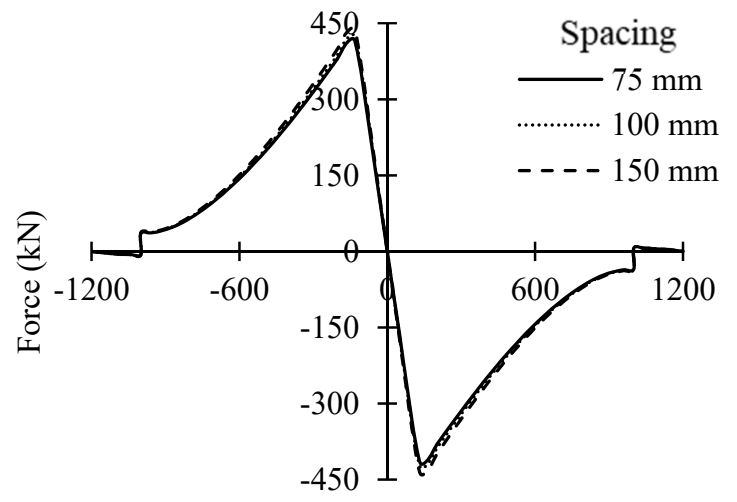

Position from the center of the beam (mm)

(a)

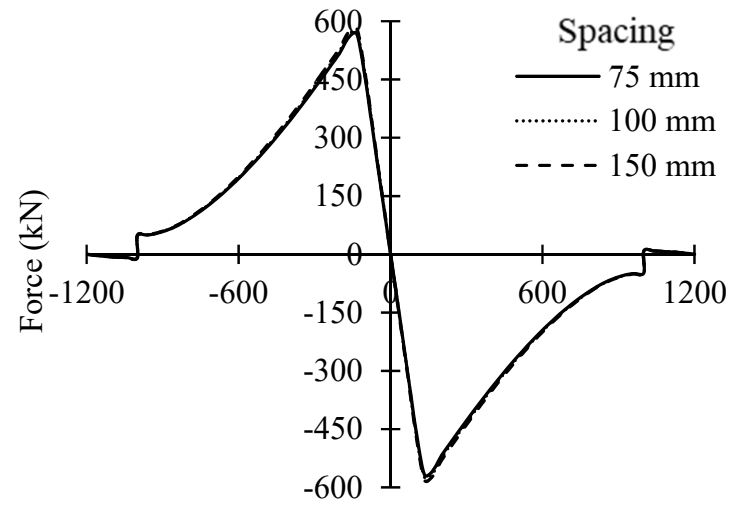

Position from the center of the beam (mm)

(b)

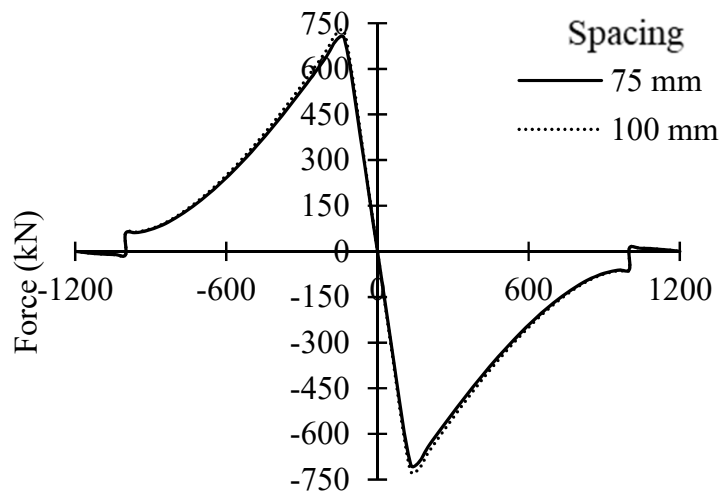

Position from the cemter of the beam (mm) (c)

Fig. 9. Dynamic shear force distribution at $t=1 \mathrm{~ms}$ for: (a) Group 1 beams, (b) Group 2 beams, and (c) Group 3 beams (See Table 1) 


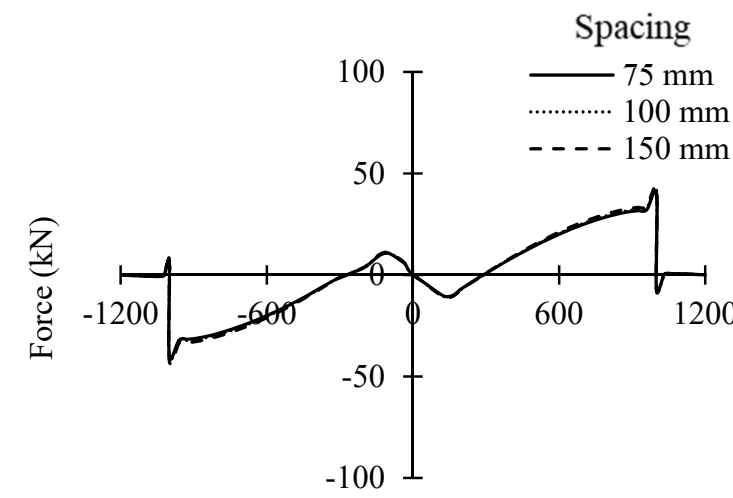

Position from the center the beam (mm)

(a)

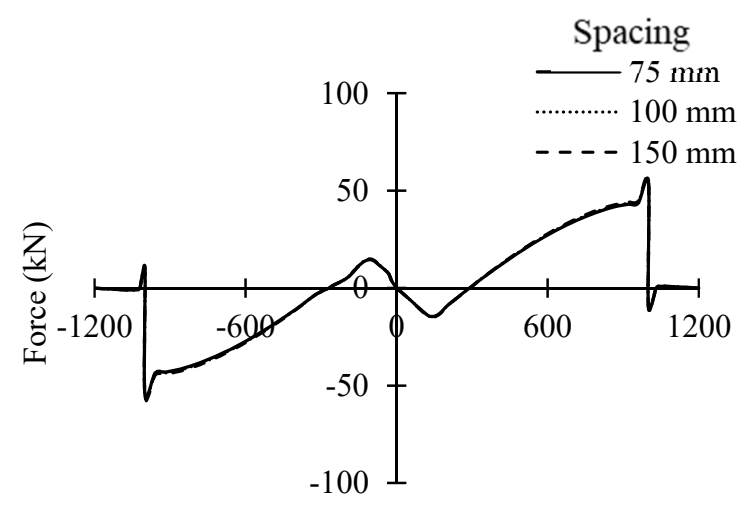

Position from the center the beam (mm)

(b)

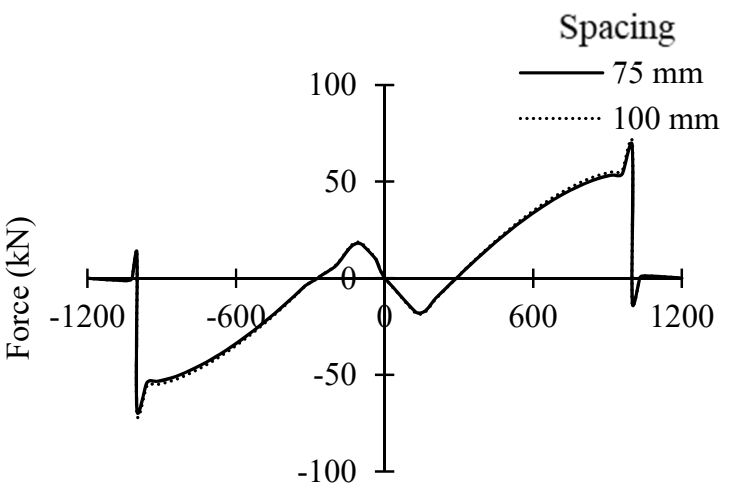

Position from the center the beam (mm)

Fig. 10. Dynamic shear force distribution at $t=5 \mathrm{~ms}$ for: (a) Group 1 beams, (b) Group 2 beams, and (c) Group 3 beams (See Table 1) 


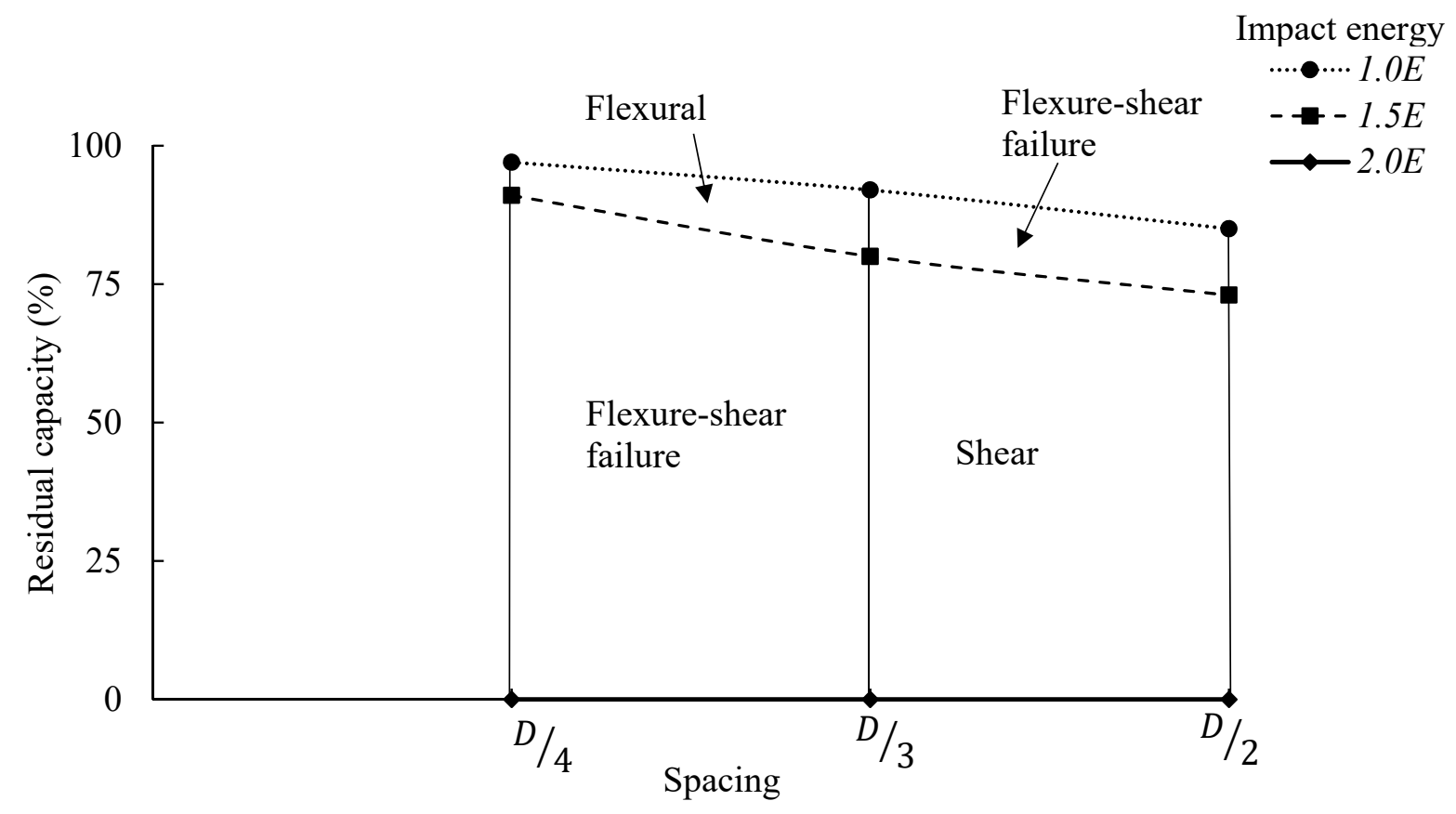

Fig. 11. Residual load-carrying capacities of the beams with different shear capacities 